\title{
Lojalność względem Kościoła w świetle marketingu partnerskiego
}

\section{LOYALTY TO THE CHURCH IN THE LIGHT OF AFFILIATE MARKETING}

The article concerns the way of developing loyalty to the Church. The necessity to develop loyalty with regard to the people who constitute the ecclesial community and to build it with regard to the people whose loyalty has decreased is an urgent problem nowadays. The processes of laicization and secularization in Poland influence loosening of the bonds with the Church and often result in leaving the Church. This situation forces priests to counteract the effects of the processes. In their efforts they can make use of the principles developed on the basis of economics. The ones which are particularly effective, as it seems, are the principles used in the affiliate marketing which aims at customer retention and which is based on cooperation. The article takes up the issue of developing loyalty to the Church through common values, strengthening self-confidence, maintaining contacts and recognition as well as through engagement and prizes.

Key words: the Church, pastoral care, loyalty, marketing, affiliate marketing, relationship marketing.

Współczesne przemiany społeczno-religijne w Polsce cechują się sekularyzacją przestrzeni publicznej i laicyzacją życia ludzi wierzących. Urzędowa ateizacja społeczeństwa polskiego, jaka miała miejsce w czasach PRL, jest zastępowana laickimi wpływami kultury 
Teologia pastoralna

zachodniej. Procesy sekularyzacyjne nie są całkowicie spontaniczne, ale są wspierane przez różnorakie siły, zarówno krajowe, jak i zagraniczne, za pomocą mediów. Zwolennicy liberalizmu nie są neutralni wobec religii i ludzi wierzących, lecz - wbrew głoszonym tezom, wzywającym chrześcijan do tolerancji - sami wykazują daleko idąca nietolerancję względem nich. Taka postawa sprzyja rozwijaniu się konfliktu ideowego i religijnego na linii wierzący - niewierzący, który przebiega często w sposób zakamuflowany i niemal niezauważalny dla zwykłych obywateli. Dzięki intensywnej promocji liberalnego stylu życia, zorientowanego materialistycznie i docześnie, przedstawianego w atrakcyjnej formie, wielu chrześcijan, zwłaszcza względnie słabo związanych z Kościołem, jeszcze bardziej rozluźnia swoje więzi z nim. Wprawdzie formalne wystąpienia z Kościoła nie są w Polsce liczne, ale faktyczne zerwanie więzów lub ich poważne osłabienie staje się udziałem coraz liczniejszej grupy osób.

Kościół w Polsce po raz kolejny jest stawiany w sytuacji konfrontacji z przeciwną ideologią. Sytuacja ta jest, zdaniem niektórych autorów, bardziej skomplikowana niż w czasach PRL, ponieważ przeciwnik jest trudniejszy do określenia i zidentyfikowania. Odpowiedzialni za duszpasterstwo, a także pastoraliści są świadomi położenia, w jakim Kościół się znajduje, dlatego usiłują przeciwdziałać procesom zachodzącym w jego otoczeniu. Korzystając z doświadczeń Kościołów lokalnych oraz wskazań papieża Franciszka, podejmują dzieło nowej ewangelizacji, skłaniając się ku nowym środkom pastoralnym oraz próbując wykrzesać nowy zapał duszpasterski i apostolski ${ }^{1}$.

W dziele nowej ewangelizacji pomocne może okazać się korzystanie z nauk o zarządzaniu. Zwłaszcza stosowany coraz częściej w ostatnich dziesięcioleciach marketing partnerski, zwany także marketingiem relacji, skupiający się na utrzymaniu klienta ${ }^{2}$, może okazać się pomocny w budowaniu lojalności wierzących do Kościoła. Programy lojalnościowe, stosowane w firmach produkujących towary przemysłowe, jak również w firmach usługowych, obejmują różnorakie elementy, obliczone na długotrwałe lub krótkotrwałe relacje z klientem oraz odwołujące się do jego sfery intelektualnej i emocjonalnej. Są to: wartości, poczucie własnej wartości, ciągłe kontakty, rozpoznanie, nagrody oraz zaangażowanie czyli włączenie ${ }^{3}$.

1 Por. K. Święs, Aktualne wyzwania nowej ewangelizacji w Polsce, [w:] Polskie drogi nowej ewangelizacji, K. Święs, D. Lipiec (red.), Lublin 2014, s. 23-41. 


\section{Lojalność do Kościoła przez wartości}

Kościół „oferuje” najwyższą możliwą wartość, którą jest Zbawienie rozumiane jako wspólnota z Bogiem. Jest ono rozumiane jako wspólnota w wymiarze doczesnym i wiecznym. Zjednoczenie z Bogiem jest spełnieniem wszystkich pragnień człowieka i jego szlachetnych dążeń. $\mathrm{Z}$ punktu widzenia marketingu jest to najlepsza możliwa jakość, jaką oferuje się człowiekowi, i którą wszyscy powinni posiąść.

W celu realizacji posłannictwa zbawczego Kościół został wyposażony w różnorodne środki, będące również wartościami w rozumieniu ekonomicznym. Są to: Słowo Boże, sakramenty i modlitwa oraz miłość chrześcijańska. Objawienie Boże, zawarte w Piśmie Świętym i Tradycji jest samą prawdą, dlatego ma wartość większą, niż jakakolwiek wiedza i mądrość ludzka. Wartość Słowa Bożego wynika z jego pochodzenia: Bóg nie może się mylić, nie może także wprowadzać człowieka w błąd. Wiedza, którą daje człowiekowi jest pewna i pełna. Dotyczy ona świata stworzonego i nadprzyrodzonego, człowieka - jego godności, pochodzenia, jego życia - sensu i celu, a także relacji człowieka do Boga. Wbrew rozpowszechnianym twierdzeniom, nie jest ona sprzeczna z wiedzą naukową, dlatego że stwórcą świata, poznawanego drogą badań, jest Bóg - Dawca Objawienia. Ponieważ Objawienie odgrywa decydującą rolę w budowaniu światopoglądu, ma ono zasadnicze znaczenie dla człowieka, a przez to jest wartością samą w sobie ${ }^{4}$.

Podobnie sakramenty, są środkiem łączącym człowieka z Bogiem, zwłaszcza Eucharystia, która jednoczy z Nim, dając przedsmak komunii w wieczności. Sakramenty, tak jak Słowo Boże, stanowią wartość, której nie można zastąpić inną wartością, gdy chodzi o nadanie sensu i ostatecznego celu ludzkiej egzystencji. Podobną rolę pełni modlitwa, której Kościół uczy. Ona również wiąże człowieka z Bogiem, a także z innymi ludźmi, tworząc z nich wspólnotę - jeden organizm, mający własną egzystencję.

Również chrześcijańska miłość jest wartością, której siła jest zdolna przemieniać człowieka. Dzięki miłości człowiek może nie tylko przekraczać własne słabości, lecz także wykraczać przed siebie ku innym, nawet wbrew sobie. Miłość umożliwia budowanie wspólnoty ludzkiej opartej nie na konsensusie interesów, lecz na dążeniu do dobra drugiego człowieka, a przez to osiąganiu własnego dobra. Ten paradoks miłości, która daje człowiekowi szczęście, gdy ten daje szczęście innym, jest novum chrześcijaństwa. Dzięki miłości przezwyciężane jest

Por. M. Rusecki, Z teologii wiary, [w:] K. Kaucha, A. Pietrzak, W. Rebeta (red.), Rok wiary - rok odnowy, Lublin 2013, s. 23-26. 
nie tylko prawo siły, ale następuje humanizacja życia społeczeństw i poszczególnych ludzi ${ }^{5}$.

Na tych podstawach została zbudowana cywilizacja chrześcijańska. Jej podstawową wspólnotą jest rodzina. Model rodziny chrześcijańskiej obejmuje relacje między kobietą i mężczyzną, a także problematykę zrodzenia i wychowania potomstwa. Wiąże się ona z problematyką seksualności człowieka, w tym także wartość czystości.

Chrześcijański charakter cywilizacji europejskiej przejawia się także w sposobie budowania życia społecznego, opartego na zasadach

Teologia pastoralna dobra wspólnego, pomocniczości i solidarności. Realizacja funkcji wychowawczej Kościoła przyczyniła się do rozwoju duchowego ludzi i podniesienia poziomu kulturowego społeczeństw. Pod wpływem chrześcijan nastąpił rozwój duchowy i materialny ludów i narodów. Znaczący jest wkład chrześcijan w rozwój nauki i techniki, który wypływa nie tyle z ich formalnej przynależności do wspólnoty kościelnej, ile ze sposobu myślenia i wartościowania, wynikającego z orędzia ewangelicznego. Ceniona, także współcześnie, jest edukacja prowadzona przez instytucje kościelne. Wszystko to sprawia, że Kościół dysponuje „marką”, dostrzeganą nawet przez jego adwersarzy. Pojawiające się obecnie różnorakie wystąpienia przeciwko Kościołowi i wywieranie nacisków, aby zmienił on swoje nauczanie i praktykę w różnorakich sprawach społecznych i moralnych, świadczy pośrednio, że jego adwersarze liczą się z nim nie tylko jako instytucją, ale przede wszystkim z jego przesłaniem.

Współczesne wystąpienia przeciwko Kościołowi zmierzają do deprecjonowania chrześcijańskiego stylu życia, zwłaszcza rodzinnego. Konieczna jest zatem jego promocja. Przyjmowanie pozycji obronnej w działalności pastoralnej, a zwłaszcza w public relations sprawia, że Kościół stawia siebie w pozycji słabszego, co w odbiorze skutkuje postrzeganiem go jako winnego, który musi się tłumaczyć z wciąż nowych zarzutów. Te zaś są coraz bardziej absurdalne, chociaż przez coraz większą grupę osób uznawane za zasadne. Istnieje zatem potrzeba przedstawiania pozytywnego obrazu Kościoła, a przede wszystkim pozytywnego obrazu chrześcijaństwa ${ }^{6}$. Wspominanie dawnych dokonań, chociaż potrzebne, nie może być dominujące w kreowaniu obrazu chrześcijaństwa, ponieważ utrwala głoszony przez przeciwników pogląd, że chrześcijaństwo było dobre w przeszłości, ale obecnie

Por. W. Przygoda, Postuga charytatywna Kościołów Polsce, Lublin 2004, s. 78-90.

Por. M. M. Przybysz, Public relations w nowej ewangelizacji, [w:] W. Przygoda, E. Robek (red.), Ewangelizacja odpowiedzia Kościoła w Polsce na wyzwania wspótczesności, Sandomierz 2011, s. 414-417. 
i w przyszłości nie sprawdzi się jako fundament życia jednostek i społeczeństw. Bardziej niż dotychczas istnieje potrzeba promocji chrześcijańskiego stylu życia: ewangelicznej hierarchii wartości, chrześcijańskiej wizji płciowości, małżeństwa i rodziny oraz chrześcijańskich zasad w życiu społecznym. Potrzeba także wskazywać na rozwiązywanie problemów społecznych i trudności osób indywidualnych, w tym także egzystencjalnych, w oparciu o Ewangelię. Chodzi zatem bardziej o promocję tego, co Kościół proponuje, niż o promocję samego Kościoła. Kościół ma bowiem rolę służebną wobec świata, jak uczy Sobór Watykański II (KDK 3).

\section{Lojalność względem Kościoła przez poczucie własnej wartości}

Poczucie własnej wartości u klienta rodzi się wtedy, gdy kupując produkt lub usługę danego przedsiębiorstwa jest z tego powodu dumny. Nabywanie produktu lub usługi sprawia, że człowiek czuje się kimś ważnym lub wyjątkowym, albo przez innych za takiego jest uważany. Korzystanie z produktów lub usług danej firmy sprzyja zaspokajaniu niektórych potrzeb psychicznych człowieka, jak poczucie uznania, poczucie własnej wartości. Firma taka posiada markę, która nobilituje osoby korzystające z oznaczonych nią produktów i usług?

W społeczeństwie tradycyjnym Kościół cieszył się dobrą „marką”. Przez realizację funkcji wychowawczej oraz funkcji kontroli społecznej troszczył się o podnoszenie poziomu kultury, zarówno kultury wyższej, jak i kultury życia codziennego wierzących. Ta troska o doskonalenie życia społecznego i życia poszczególnych osób cieszyła się poparciem, zaś sam Kościół pozycjonowała wysoko jako instytucję służącą rozwojowi cywilizacyjnemu i realizującą na ziemi misję zleconą przez swego Założyciela. Uczestnictwo w życiu Kościoła na szczeblu parafialnym i ponadparafialnym postrzegano jako działalność nobilitującą. Podobnie postrzegane było członkostwo w zrzeszeniach religijnych, ponieważ dawało ono „korzyści” w postaci formacji intelektualnej, duchowej i ludzkiej. Jako nobilitujące uważano podejmowanie takich działań jak np. służenie do Mszy św., noszenie baldachimu, chorągwi i feretronów podczas procesji. Nobilitujące było pełnienie etatowych urzędów w parafii jako kościelny czy organista.

Aktualnie w przestrzeni publicznej można dostrzec proces osłabiania,„marki” Kościoła, a przez to jego pozycji w społeczeństwie. Służą temu działania mające na celu ośmieszanie Kościoła jako wspólnoty

J. Horovitz, Strategia obstugi klienta..., op. cit., s. 114. 
Teologia pastoralna

i instytucji, jego urzędowych przedstawicieli, jak również zaangażowania w działalność kościelną. Sprzyjają temu skandale z udziałem duchownych. Pojedyncze przypadki są uogólniane i wyolbrzymiane, a w sytuacji braku skandalu przywoływane są wydarzenia z przeszłości lub z innego miejsca ${ }^{8}$.

Mimo działań zmierzających do osłabienia „marki” Kościoła, wiele różnorakich inicjatyw podejmowanych przez katolików cieszy się uznaniem w społeczeństwie, także wśród niechrześcijan. Wzmacniają one jego wizerunek, a przede wszystkim umacniają jego obecność w przestrzeni publicznej. Do takich działań należy szkolnictwo katolickie, mające dobrą renomę - „markę”. Opieka w żłobkach i przedszkolach prowadzonych przez instytucje kościelne, kształcenie w szkołach i uczelniach katolickich jest oceniane pozytywnie i lokowane na poziomie ponadprzeciętnym. Do takich placówek wychowawczych i edukacyjnych posyłane są dzieci rodziców nierzadko słabo związanych z Kościołem, a nawet deklarujących się jako niewierzący. Podobnie postrzegane są instytucje opiekuńcze prowadzone przez podmioty kościelne, jakimi są domy pomocy społecznej, hospicja i im podobne. Cenione są one nie tylko za profesjonalizm pracujących tam osób, ale głównie za szacunek dla podopiecznych i ofiarną posługę względem nich.

Wzmocnienie pozycji Kościoła, aby przynależność do niego była uważana za nobilitującą, możliwe jest na dwa sposoby, które należy realizować łącznie. Są to: podniesienie jakości jego życia i posługiwania oraz public relations. Zaufanie do Kościoła zasadza się głównie na tym, że jest postrzegany jako wspólnota i instytucja solidna, uczciwa i solidaryzująca się ze słabymi. Zwłaszcza solidność i uczciwość są cechami pożądanymi w społeczeństwie polskim. Solidność jest cechą określającą jakość produktu lub usługi podmiotów w przestrzeni publicznej, zaś uczciwość jest cechą ich pracowników9. Na niej buduje się zaufanie. Podobnie w Kościele: solidność jest cechą sprawowanych posług wobec wiernych i ewangelizacji skierowanej do niewierzących lub dystansujących się, natomiast uczciwość w relacjach duszpasterzy i ich pomocników w stosunku do wierzących. Sprzyjają one budowaniu zaufania do Kościoła w wymiarze całościowym oraz nawiązywaniu (red.), Polskie drogi nowej ewangelizacji, Lublin 2014, s. 179-183. 
i rozwijaniu relacji między odpowiedzialnymi za duszpasterstwo a jego adresatami ${ }^{10}$.

W public relations konieczna jest troska o pozytywny wizerunek Kościoła w świecie i wśród wierzących. W programach duszpasterskich stałe miejsce powinno znaleźć PR. Kościół powinien także planować relacje $\mathrm{z}$ otoczeniem. Konieczne jest również umiejętne zarządzanie wizerunkiem Kościoła, zwłaszcza w sytuacjach kryzysowych, nagłaśnianych szeroko przez media liberalne. Umiejętne posługiwanie się narzędziami PR pomaga wzmacniać pozytywny obraz Kościoła ${ }^{11}$.

\section{Lojalność przez kontakty i rozpoznawanie}

Marketing partnerski zmierza do nawiązywania i utrzymywania długotrwałych relacji z klientem. Wymagają one pewnego wysiłku, związanego z prowadzeniem baz danych, kierowaniem do klientów nowych ofert i tym podobnych działań. Zwraca się uwagę, że znaczącą rolę w podtrzymywaniu relacji odgrywają bezpośrednie kontakty.

Kościół wykształcił na przestrzeni wieków wiele różnorakich form nawiązywania i podtrzymywania kontaktów. Na szczeblu parafialnym kontakty duszpasterzy z wiernymi podtrzymywane są poprzez odwiedziny w domach parafian, w ich miejscach pracy, odpoczynku, a także poprzez odwiedzanie duszpasterzy w kościołach, domach parafialnych. Za szczególnie cenne uważa się kontakty w domach parafian. Należą do nich te, które mają miejsce podczas wizyty duszpasterskiej zwanej kolędą. Atmosfera domu rodzinnego, w którym wierni czują się bezpiecznie sprzyja otwarciu na odwiedzających duchownych, proponowaną przez nich tematykę rozmów, a także proponowaniu własnych tematów, związanych z życiem religijnym, osobistym lub rodzinnym. Celem wizyty kolędowej jest nie tylko sprawdzenie stanu religijności parafian i pomoc w pokonywaniu problemów religijnych i egzystencjalnych, lecz także podtrzymywanie i rozwijanie więzi między nimi a wspólnotą parafialną ${ }^{12}$.

Wskazuje się także na potrzebę nawiązywania kontaktów z nowo przybyłymi rodzinami do parafii poprzez odwiedzanie ich w domach, jak również odwiedzanie młodych małżeństw. Często przynajmniej

10 Por. T. Mirończuk, W trosce o odpowiedzialne postawy pastoralne, [w:] I. Celary, G. Polok(red.),Odpowiedzialność w przestrzeni społeczno-pastoralnej, Katowice 2013, s. 241-243.

11 M. M. Przybysz, [w:] Ewangelizacja odpowiedzia Kościoła..., op. cit., s. 402-408.

12 Por. W. Śmigiel, Wizyta duszpasterska, zwana kolęda, jako szansa na ewangelizację osób dystansujących się od Kościoła, „Teologia Praktyczna” 14(2013), s. 118. 
jedno z małżonków pochodzi z innej parafii; dzięki odwiedzinom można nie tylko pomóc w rozwoju wzajemnych więzi między małżonkami, towarzysząc im w pierwszych miesiącach po ślubie, ale także rozwijać ich więzi z parafią. Odwiedziny duszpasterskie dają okazję do składania propozycji dalszego angażowania się w życie wspólnoty parafialnej, zwłaszcza w ruchach i stowarzyszeniach religijnych ${ }^{13}$.

Za szczególnie cenne uważane są przez ekonomistów te kontakty, które są inicjowane przez klientów. Wynikają one z ich potrzeb, które skłaniają do podjęcia inicjatyw zmierzających do ich zaspokojenia ${ }^{14}$. Analogicznie można postrzegać kontakty nawiązywane przez wierzących lub inne osoby z duszpasterzami parafialnymi. W perspektywie tych kontaktów należy postrzegać zwłaszcza relacje nawiązywane lub realizowane w kancelarii parafialnej. Takie wydarzenia o charakterze rodzinnym i religijnym jak: ślub, pogrzeb, chrzest dziecka i im podobne skłaniają do przyjścia osoby nie tylko głęboko wierzące i mające silne więzy z Kościołem, lecz także dystansujące się lub nawet niewierzące. Nawiązanie kontaktu z osobami niemającymi pogłębionych więzi z Kościołem, nawet wymuszone sytuacją życiową i odbywające się w atmosferze uprzedzeń i nieufności, stwarza okazję do wzajemnego poznania się, a następnie rozwijania kontaktu i budowania więzi z Kościołem. Spotykane coraz częściej w kancelarii parafialnej nietaktowne zachowanie przychodzących utrudnia kontakt z nimi. Pozwala jednak duszpasterzom na poznanie ich rzeczywistych potrzeb religijnych, nierzadko przez nich samych nieuświadomionych. Postawienie diagnozy duszpasterskiej w odniesieniu do takich osób umożliwia określenie sposobów ich zaspokojenia oraz podjęcia odpowiednich form i metod pastoralnych ${ }^{15}$.

W przeszłości owocne były kontakty inicjowane przez duszpasterzy. Starali się oni odczytywać potrzeby społeczne, kulturalne czy religijne wiernych, aby pobudzać ich do pogłębiania życia duchowego. Duchowni inicjowali kontakty przez zainteresowanie sportem, muzyką, dzięki czemu powstawały kluby sportowe, kluby parafialne, zespoły muzyczne i schole. Na ich bazie organizowano sportowe ligi diecezjalne, parafiady, konkursy i festiwale muzyczne oraz wiele różnorodnych imprez o charakterze kulturalnym i religijnym. Kontakty inicjowane

13 Por. D. Lipiec, Odwiedziny duszpasterskie rodzin, [w:] R. Kamiński, G. Pyźlak, J. Goleń (red.), Duszpasterstwo rodzin. Refleksja naukowa i dziatalność pastoralna, Lublin - Rzeszów 2013, s. 418-430.

14 J. Horovitz, Strategia obstugi klienta..., op. cit., s. 116.

15 Por. A. Kaczor, Kancelaria parafialna, [w:] R. Kamiński (red.), Teologia pastoralna, t. 2., Lublin 2002, s. 86-93. 
i podtrzymywane w oparciu o takie inicjatywy były traktowane jako punkt wyjścia do właściwej formacji chrześcijańskiej. Nie wszystkie jednak kontakty były systematycznie rozwijane. Powodem tego były m.in. odmienne oczekiwania uczestników, którzy korzystali z „oferty” kulturalnej lub rekreacyjnej Kościoła, lecz nie byli zainteresowani dalszą formacją. Innym powodem były także działania duszpasterzy, którzy skupiali uwagę na tym, co przyciągało zainteresowanych, ale nie zawsze rozwijali dalszą pracę formacyjną. Takie działania kierowane były głównie do ludzi młodych, których starano się zainteresować Kościołem, przedstawiając go w sposób atrakcyjny.

Wiele inicjatyw podejmowanych w przeszłości nie jest obecnie rozwijanych, głównie ze względu na trudności w zainteresowaniu ludzi, zwłaszcza młodych, życiem Kościoła. Także indywidualizacja życia społecznego, skupianie się jego uczestników przede wszystkim na własnych potrzebach i doznaniach oraz zaspokajaniu ich w sposób indywidualny, stanowią trudność w nawiązywaniu i podtrzymywaniu kontaktów przez duszpasterzy. Konieczne jest, jak się wydaje, odczytanie na nowo potrzeb wierzących, zarówno ludzi młodych jak dorosłych, aby skonstruować adekwatne sposoby oddziaływania na nich i budowania kontaktów. Dotychczasowe, sprawdzone i skuteczne w przeszłości, nie gwarantują efektywności w odniesieniu do ludzi współczesnych.

Budowanie lojalności przez rozpoznawanie polega na dostrzeganiu człowieka, jego indywidualności, odrębności i wyjątkowym traktowaniu go. W firmach produkcyjnych, a przede wszystkim usługowych, strategia budowania lojalności przez rozpoznawanie realizowana jest przez okazywanie klientowi, że jest on znany, a kierowana do niego oferta jest dostosowana do jego indywidualnych potrzeb. Jego obsługa ma charter indywidualny i sprawia wrażenie wyjątkowej. Kierowane są do niego podziękowania za współpracę i zaangażowanie we wspólne działania, jego rady i sugestie są słuchane. Wszystkie te zabiegi mają podkreślać jego wyjątkowość oraz wagę jego wskazówek dla funkcjonowania przedsiębiorstwa ${ }^{16}$.

W duszpasterstwie dawno już zwrócono uwagę na potrzebę indywidualnych kontaktów z wiernymi. Za wzorcową parafię uznano taką, w której proboszcz zna osobiście parafian, a oni znają się nawzajem. Bezpośrednie interakcje, w jakie wchodzą proboszcz i parafianie sprzyjają budowaniu lojalności względem Kościoła i budowaniu jego wspólnotowości ${ }^{17}$. Istniejąca współcześnie anonimowość w parafiach,

16 J. Horovitz, Strategia obstugi klienta..., op. cit., s. 118.

$17 \quad$ Por. A. Żądło, Parafia w trzecim tysiącleciu, Kielce 1999, s. 54-92. 
zwłaszcza dużych, oraz migracja ludności z parafii do parafii nie sprzyja budowaniu kontaktów duszpasterzy z wiernymi, chociaż pragną ich zarówno duchowni, jak i świeccy. Ci drudzy cenią indywidualne traktowanie przez księży, które przejawia się w rozmowach po Mszy św., w ciepłym klimacie rozmów w kancelarii czy zakrystii, w rozpoznawaniu w miejscach publicznych. Obecnie, bardziej niż dotychczas, konieczne są osobiste i zindywidualizowane kontakty duszpasterzy z wiernymi, zasadzające się na szacunku dla nich i dowartościowaniu ich obecności.

\section{Lojalność przez zaangażowanie i nagrody}

Budowanie lojalności przez zaangażowanie ma miejsce wtedy, gdy klient jest włączany w życie firmy i uczestniczy w rozwiązywaniu jej problemów. W ten sposób sprawy firmy stają się jego sprawami i następuje, przynajmniej częściowa, identyfikacja klienta z przedsiębiorstwem ${ }^{18}$. Sobór Watykański II wskazuje, że Kościół jest wspólnotą składającą się z osób dążących do Zbawienia, opierających swe życie na wskazaniach zawartych w Objawieniu Bożym, budujących relacje na miłości braterskiej. Duszpasterstwo dąży do aktywizacji religijnej członków Kościoła. Wszyscy oni mogą angażować się w działalność zrzeszeń religijnych, a zwłaszcza ruchów, przeżywających dynamiczny rozwój w dobie posoborowej ${ }^{19}$. Szczególnym sposobem zaangażowania świeckich w życie Kościoła jest członkostwo w radach diecezjalnych i parafialnych, zwłaszcza radach duszpasterskich.

Uczestnictwo w diecezjalnych i parafialnych radach duszpasterskich wiąże się z udziałem w odpowiedzialności za Kościół lokalny. Łączy więc członków tych gremiów ze wspólnotą kościelną ściśle i sprzyja coraz większemu utożsamianiu się z nią. Uczestnictwo w radach duszpasterskich mobilizuje jednak nie tylko ich członków. Jednym z celów rad jest bowiem aktywizacja ogółu diecezjan i parafian przez pobudzanie ich do coraz szerszego włączania się w życie własnych wspólnot. Zwraca się uwagę, żeby włączanie świeckich w rady duszpasterskie związane było z przekazywaniem realnej odpowiedzialności za życie wspólnoty Kościoła. Formalne uczestnictwo w nich nie tylko

\footnotetext{
18 J. Horovitz, Strategia obstugi klienta..., op. cit., s. 124.

19 Zob. II Polski Synod Plenarny. Potrzeba i zadania nowej ewangelizacji na przeŁomie II i III Tysiaclecia Chrześcijaństwa nr 43, Poznań 2002, s. 22.
} 
nie pogłębia aktywności i odpowiedzialności wiernych za Kościól, ale zniechęca do dalszej aktywności. Ich bierność zniechęca następnie inne osoby ${ }^{20}$.

Włączanie w aktywną działalność w Kościele dokonuje się także przez uczestnictwo w zrzeszeniach religijnych. Wielorakie stowarzyszenia, ruchy i małe grupy religijne proponują różne formy aktywności, zgodne z ich charyzmatem. Oferują one możliwość formacji chrześcijańskiej członków, a w jej ramach pogłębianie więzów ze wspólnotą Kościoła. Zrzeszenia religijne stają się przez to platformami, przez które wierni włączają się w życie parafii, diecezji i Kościoła powszechnego. Dzięki działalności zrzeszeń religijnych parafia staje się wspólnotą wspólnot ${ }^{21}$.

Za słabość zrzeszeń religijnych w Polsce uważane jest przeakcentowanie zaspokajania potrzeb religijnych w formacji ich członków. Zbyt mało natomiast akcentowany jest - w niektórych z nich - aspekt apostolski formacji, związany z przyjmowaniem odpowiedzialności za Kościół oraz bardziej aktywnym angażowaniem się w jego działalność w celu powiększania dobra wspólnego ${ }^{22}$. Może to skutkować traktowaniem zrzeszeń religijnych jako swego rodzaju grup terapeutycznych, w których uczestnictwo ma charakter głównie utylitarny. Włączanie w zrzeszenia religijne, w świetle marketingu partnerskiego, może odbywać się ze względu na realizację indywidualnych potrzeb duchowych i egzystencjalnych, jednak formacja realizowana w nich powinna prowadzić do głębszego zaangażowania i podejmowania odpowiedzialności za Kościół.

Budowanie lojalności względem Kościoła przez nagrody ma bardzo ograniczone zastosowanie w jego praktyce. Podkreśla się, że Bóg powołuje człowieka z miłości i w miłości, a także miłości od człowieka oczekuje. Życie wspólnoty kościelnej opiera się na bezinteresownej miłości braterskiej, wywodzącej się ze zbawczej miłości Ojca. Świadectwo życia chrześcijańskiego, do jakiego zobowiązani są wierzący, wyraża się w bezinteresownych czynach. Także zorganizowana działalność charytatywna Kościoła nie jest ukierunkowana na werbowanie nowych członków i umacniania obecności dotychczasowych, ale na bezinteresowną służbę bliźniemu będącemu w potrzebie.

$20 \quad$ Por. T. Wielebski, M. Tutak, Diecezjalne Rady Duszpasterskie w Polsce. Między ideałem a rzeczywistościa, „Teologia Praktyczna” 13(2012), s. 29-32; T. Wielebski, Rady duszpasterskie $w$ Polsce $w$ stużbie budowania communio Kościoła, „Ateneum Kapłańskie” 165(2015), z. 2, s. 277-283.

Por. A. Żądło, Parafia w trzecim tysiącleciu..., op. cit., s. 98-100. 
Teologia pastoralna

Programy lojalnościowe oparte na nagrodach kieruje się głównie do dzieci. Najbardziej znane spośród nich są inicjatywy zmierzające do zachęcania ich do systematycznego uczestnictwa w nabożeństwach maryjnych w maju i październiku. Wtedy to rozdaje się obrazki, naklejki i inne przedmioty, odmienne każdego dnia, zaś na koniec najaktywniejszych uczestników nagradza się. Podobnie nagradza się uczestnictwo we Mszach św. roratnych, obchodach pierwszych piątków miesiąca i innych wydarzeniach religijnych. Nagrody przyznawane bywają także dzieciom i młodzieży za systematyczne zaangażowanie w różnorakie inicjatywy duszpasterskie w parafii. Nagradzani są najaktywniejsi ministranci, lektorzy, bielanki. Formą nagradzania jest organizowanie wspólnych wyjazdów na wycieczki czy pielgrzymki dla wszystkich ministrantów, lektorów i członków innych grup parafialnych, bez względu na stopień zaangażowania. Nagrody nie mają formy pieniężnej, aby unikać wrażenia płacenia za zaangażowanie w Kościele. Duszpasterze starają się natomiast nadawać charakter wychowawczy i edukacyjny przyznawanym nagrodom i wyróżnieniom, by kierowały one uwagę ku większym, duchowym wartościom.

\section{Zakończenie}

Stosujący marketing partnerski w sferze towarów i usług starają się wpływać zarówno na sferę intelektualną jak emocjonalną klienta, mając na uwadze transakcje sporadyczne, nieciągłe, jak i długotrwałe relacje z klientami. Mają oni za cel przyciągnięcie nowych klientów oraz ich utrzymanie. Celem ekonomicznych przedsiębiorstw przemysłowych i usługowych jest zysk i własny rozwój. Chociaż celem Kościoła nie jest zysk materialny i umacnianie pozycji w świecie w rozumieniu ekonomicznym, to rozumienie i stosowanie mechanizmów marketingu partnerskiego może pomóc w realizacji jego posłannictwa. Konieczne jest przy tym traktowanie podmiotowe osób, do których kierowana jest działalność pastoralna, aby uniknąć wrażenia, że są oni jedynie środkiem do osiągnięcia przez Kościół ukrytych celów. Narzędzia marketingu partnerskiego mogą przyczynić się do zwiększenia skuteczności duszpasterstwa, zwłaszcza zrozumienie rzeczywistych potrzeb religijnych i egzystencjalnych wierzących. Może to pomóc w konstruowaniu form i metod duszpasterskich adekwatnych do potrzeb wiernych i ich sytuacji życiowych.

Słowa kluczowe: Kościół, duszpasterstwo, lojalność, marketing, marketing partnerski, marketing relacji. 


\section{Bibliografia}

1. II Polski Synod Plenarny, Potrzeba i zadania nowej ewangelizacji na przetomie II i III Tysiaclecia Chrześcijaństwa, Poznań 2002.

2. Furtak R., Marketing partnerski na rynku ustug, Warszawa 2003.

3. Gordon I. H., Relacje z klientem. Marketing partnerski, Warszawa 2001.

4. Horovitz J., Strategia obstugi klienta, Warszawa 2006.

5. Kaczor A., Kancelaria parafialna, [w:] R. Kamiński (red.), Teologia pastoralna, t. 2, Lublin 2002.

6. Lipiec D., Duszpasterstwo parafialne wobec wspótczesnych wyzwań, „Ateneum Kapłańskie" 165(2015), z. 2.

7. Lipiec D., Odwiedziny duszpasterskie rodzin, [w:] R. Kamiński, G. Pyźlak, J. Goleń (red.), Duszpasterstwo rodzin. Refleksja naukowa i dziatalność pastoralna, Lublin - Rzeszów 2013.

8. Mirończuk T., W trosce o odpowiedzialne postawy pastoralne, [w:] I. Celary, G. Polok (red.), Odpowiedzialność $w$ przestrzeni społeczno-pastoralnej, Katowice 2013.

9. Przybysz M., Public relations $w$ nowej ewangelizacji, [w:] K. Święs, D. Lipiec (red.), Polskie drogi nowej ewangelizacji, Lublin 2014.

10. Przybysz M. M., Public relations w nowej ewangelizacji, [w:] W. Przygoda, E. Robek (red.), Ewangelizacja odpowiedzia Kościoła w Polsce na wyzwania wspótczesności, Sandomierz 2011.

11. Przygoda W., Postuga charytatywna Kościołów Polsce, Lublin 2004.

12. Rusecki M., Z teologii wiary, [w:] K. Kaucha, A. Pietrzak, W. Rebeta (red.), Rok wiary - rok odnowy, Lublin 2013.

13. Sobór Watykański II, Konstytucja duszpasterska o Kościele w świecie współczesnym Gaudium et spes, [w:] Sobór Watykański II, Konstytucje, dekrety, deklaracje, Poznań 1986.

14. Śmigiel W., Wizyta duszpasterska, zwana kolęda, jako szansa na ewangelizację osób dystansujących się od Kościoła, „Teologia Praktyczna” 14(2013).

15. Święs K., Aktualne wyzwania nowej ewangelizacji w Polsce, [w:] K. Święs, D. Lipiec (red.), Polskie drogi nowej ewangelizacji, Lublin 2014.

16. Wielebski T., Rady duszpasterskie w Polsce $w$ stużbie budowania communio Kościoła, „Ateneum Kapłańskie” 165(2015), z. 2.

17. Wielebski T., Tutak M., Diecezjalne Rady Duszpasterskie w Polsce. Między ideałem a rzeczywistościa, „Teologia Praktyczna”, 13(2012).

18. Żądło A., Parafia w trzecim tysiacleciu, Kielce 1999. 